\title{
Effects of Essential Oils Supplementation on Growth Performance, IgG Concentration and Fecal Noxious Gas Concentration of Weaned Pigs
}

\author{
J. H. Cho, Y. J. Chen, B. J. Min, H. J. Kim, O. S. Kwon, K. S. Shon, I. H. Kim*, S. J. Kim ${ }^{1}$ and A. Asamer ${ }^{2}$ \\ Department of Animal Resource and Sciences, Dankook University, \#29 Anseodong \\ Cheonan, Choongnam, 330-714, Korea
}

\begin{abstract}
Ninety six crossbred pigs (Landrace $\times$ Yorkshire $\times$ Duroc) were used to determine the effects of essential oils (Fresta $\mathrm{F}$ $\mathrm{Conc}^{\circledR}$ ) supplementation on growth performance, immune response and fecal noxious gas of weaned pigs. Treatments were 1) NC (negative control; basal diet without antibiotics), 2) PC [positive control; basal diet+CSP (CTC+Sulfathiazole+Penicillin) 0.1\%], 3) NCF (basal diet+Fresta F Conc ${ }^{\circledR}$ 0.03\%) and 4) PCF [basal diet+CSP (CTC+Sulfathiazole+Penicillin) 0.1\%+Fresta F Conc ${ }^{\circledR}$ 0.02\%]. From d 0 to 14, ADFI was increased in pigs fed PCF diet $(\mathrm{p}<0.05)$. From d 14 to 28, pigs fed PCF diet had greater ADG and ADFI than pigs fed NC diet $(p<0.05)$. From d 28 to 49, ADG and ADFI in pigs fed PCF diet were higher than in pigs fed NC diet $(p<0.05)$. Through the entire experimental period, ADG and ADFI in pigs fed PCF diet were the highest compared to pigs fed NC and PC diets ( $\mathrm{p}<0.05)$. There was no significant difference in fecal consistency score among the treatments ( $p>0.05$ ). No statistical differences ( $p>0.05$ ) were found in red blood cells (RBC) counts, white blood cells (WBC) counts, lymphocyte counts, total protein and albumin. Serum IgG concentration of PCF treatment was greater than that of other treatments $(\mathrm{p}<0.05)$. From $\mathrm{d} 0$ to 14 , there was no significant difference in digestibility of dry matter and nitrogen among the treatments ( $>>0.05$ ). From d 14 to 28, digestibility of dry matter in pigs fed PC, NCF and PCF diets was higher than that of pigs fed NC diet $(\mathrm{p}<0.05)$ and treatments with added essential oils were higher than other diets on digestibility of nitrogen $(\mathrm{p}<0.05)$. Also, from d 28 to 49, digestibility of nitrogen in pigs fed PCF diet was the highest among others $(\mathrm{p}<0.05)$. On d 14 and 28 , no statistical differences $(\mathrm{p}>0.05)$ were found in volatile fatty acid (VFA), ammonia nitrogen $\left(\mathrm{NH}_{3}-\mathrm{N}\right)$ and hydrogen sulfide $\left(\mathrm{H}_{2} \mathrm{~S}\right)$ concentrations among treatments. On $\mathrm{d} 49$, there was no significant difference in VFA concentration among the treatments ( $p>0.05)$. $\mathrm{NH}_{3}-\mathrm{N}$ concentration in pigs fed PCF diet was lower than in pigs fed other diets $(\mathrm{p}<0.05)$. $\mathrm{H}_{2} \mathrm{~S}$ concentration in pigs fed diets with added essential oils was lower than others. In conclusion, the results suggest that the dietary addition of essential oils and antibiotics into diets for weanling pigs improved growth performance, IgG concentration and nitrogen digestibility and decreased noxious gas concentration. Essential oils can be used to partly replace antibiotics in diets for weaned pigs without negative affects on growth performance. (Asian-Aust. J. Anim. Sci. 2006. Vol 19, No. 1 : 80-85)
\end{abstract}

Key Words : Essential Oil, Growth Performance, Blood Profile, Fecal Noxious Gas Concentration, Weaned Pigs

\section{INTRODUCTION}

A ban on antibiotics as feed additives in animal nutrition is realized since 1986 in Sweden and 1999 in Switzerland. With the restricted use or ban of dietary antimicrobial agents, we must explore new ways to improve and protect the health status of farm animals, to guarantee animal performance and to increase nutrient availability. The essential oils, organic acids, enzymes, probiotics (lactobacilli), prebiotics (oligosaccharides) and the herbs can be used as feed additives. Essential oils (also called volatile or ethereal oils) are aromatic oily liquids obtained from plant material (flowers, buds, seeds, leaves, twigs, bark, herbs, woods, fruits and roots). The term 'essential oil' is thought to be derived from the name coined in the $16^{\text {th }}$ century by the Swiss reformer of medicine, Paracelsus von Hohenheim; he named the effective component of drugs

\footnotetext{
* Corresponding Author: I. H. Kim. Tel: +82-41-550-3652, Fax: +82-41-553-1618, E-mail: inhokim@dankook.ac.kr

${ }^{1}$ Yuhan Co, Seoul, Korea.

${ }^{2}$ Delacon Phytogenic Feed Additives, Austria.

Received March 10, 2005; Accepted June 28, 2005
}

Quinta essential (Guenther, 1948). Beneficial effects of essential oils on farm animals may arise from activation of feed intake and secretion of digestive secretions, immune stimulation, anti-bacterial, coccidiostatic, antiviral and antioxidant properties (Wenk, 2003). Hong et al. (2004) reported that plant extract (citrus fruit and chestnut tree extract mixture) could be used to replace antibiotic in diets for weaned pigs without negative effects on growth performance. Holden and McKean (2002) reported that ADG and feed/gain of pigs fed 2 or $3 \%$ botanical were similar to antibiotic controls and improved over the treatment without antibiotic controls. After pigs were weaned, IgG concentration in serum was on the decrease $21.2 \mathrm{mg} / \mathrm{ml}, 16.0 \mathrm{mg} / \mathrm{ml}, 10.5 \mathrm{mg} / \mathrm{ml}$ and $6.6 \mathrm{mg} / \mathrm{ml} \mathrm{(Kim}$ et al., 1994). Wang et al. (1998) reported that eugenol in essential oils improved immune ability by increasing synthesis of IgG in body and synthesis of IgA in saliva. However, the effects of essential oils have not yet been rigorously evaluated. Our study was concerned with one of the essential oils product named Fresta F Conc ${ }^{\circledR}$ (Yuhan Co., Ltd, Seoul, Korea). The objective of this study was to evaluate the effect of essential oils supplementation on 
Table 1. Diet composition (as-fed basis)

\begin{tabular}{|c|c|c|c|c|c|c|c|c|}
\hline \multirow{2}{*}{ Ingredient (\%) } & \multicolumn{4}{|c|}{ Phase I } & \multicolumn{4}{|c|}{ Phase II } \\
\hline & NC & PC & $\mathrm{NCF}$ & PCF & NC & PC & NCF & PCF \\
\hline Extruded corn & 33.77 & 33.67 & 33.74 & 33.65 & 48.42 & 48.32 & 48.39 & 48.30 \\
\hline Extruded soybean meal & 39.42 & 39.42 & 39.42 & 39.42 & 35.07 & 35.07 & 35.07 & 35.07 \\
\hline Dried whey & 10.00 & 10.00 & 10.00 & 10.00 & - & - & - & - \\
\hline Extruded oat & 5.00 & 5.00 & 5.00 & 5.00 & 5.00 & 5.00 & 5.00 & 5.00 \\
\hline Essential oils & - & - & 0.03 & 0.02 & - & - & 0.03 & 0.02 \\
\hline Soybean oil & 4.58 & 4.58 & 4.58 & 4.58 & 4.03 & 4.03 & 4.03 & 4.03 \\
\hline Fish meal & 3.00 & 3.00 & 3.00 & 3.00 & 3.00 & 3.00 & 3.00 & 3.00 \\
\hline Monocalcium phosphate & 1.01 & 1.01 & 1.01 & 1.01 & 0.90 & 0.90 & 0.90 & 0.90 \\
\hline Organic acid & 1.00 & 1.00 & 1.00 & 1.00 & 1.00 & 1.00 & 1.00 & 1.00 \\
\hline Tricalcium phosphate & 0.79 & 0.79 & 0.79 & 0.79 & 0.98 & 0.98 & 0.98 & 0.98 \\
\hline Yeast culture & 0.60 & 0.60 & 0.60 & 0.60 & 0.60 & 0.60 & 0.60 & 0.60 \\
\hline Zinc oxide & 0.30 & 0.30 & 0.30 & 0.30 & 0.30 & 0.30 & 0.30 & 0.30 \\
\hline Salt & - & - & - & - & 0.20 & 0.20 & 0.20 & 0.20 \\
\hline Vitamin premix $^{1}$ & 0.18 & 0.18 & 0.18 & 0.18 & 0.18 & 0.18 & 0.18 & 0.18 \\
\hline Mineral premix ${ }^{2}$ & 0.13 & 0.13 & 0.13 & 0.13 & 0.13 & 0.13 & 0.13 & 0.13 \\
\hline L-lysine HCL & 0.12 & 0.12 & 0.12 & 0.12 & 0.12 & 0.12 & 0.12 & 0.12 \\
\hline CSP & - & 0.10 & - & 0.10 & - & 0.10 & - & 0.10 \\
\hline Antioxidant & 0.05 & 0.05 & 0.05 & 0.05 & 0.05 & 0.05 & 0.05 & 0.05 \\
\hline DL-methionine & 0.05 & 0.05 & 0.05 & 0.05 & 0.02 & 0.02 & 0.02 & 0.02 \\
\hline \multicolumn{9}{|l|}{ Chemical composition $^{3}$} \\
\hline ME (kcal/kg) & \multicolumn{4}{|c|}{3,336} & \multicolumn{4}{|c|}{3,336} \\
\hline Crude protein (\%) & \multicolumn{4}{|c|}{23.97} & \multicolumn{4}{|c|}{21.97} \\
\hline Lysine (\%) & \multicolumn{4}{|c|}{1.60} & \multicolumn{4}{|c|}{1.40} \\
\hline Methionine (\%) & \multicolumn{4}{|c|}{0.45} & \multicolumn{4}{|c|}{0.40} \\
\hline Calcium (\%) & \multicolumn{4}{|c|}{0.90} & \multicolumn{4}{|c|}{0.90} \\
\hline Phosphorus (\%) & \multicolumn{4}{|c|}{0.80} & \multicolumn{4}{|c|}{0.80} \\
\hline
\end{tabular}

growth performance, IgG concentration and fecal noxious gas concentration in weaning pigs.

\section{MATERIALS AND METHODS}

A total of ninety six weaned pigs with an average BW of $5.50 \pm 0.11 \mathrm{~kg}$ were used in 49 days study to investigate the effect of essential oils supplementation on growth performance of weaned pigs. Pigs were blocked by initial body weight and randomly allocated to one of four dietary treatments in a randomized complete block design. There were six replications per treatment. Dietary treatments included 1) NC (negative control; basal diet without antibiotics), 2) PC [positive control; basal diet+CSP (Chlortetracycline 100 g+Sulfathiazole 100 g+Penicillin 50 g) $0.1 \%$, 3) NCF (basal diet+Fresta F Conc ${ }^{\circledR} 0.03 \%$ ) and 4) PCF [basal diet+CSP (Chlortetracycline $100 \mathrm{~g}+$ Sulfathiazole 100 g+Penicillin 50 g) $0.1 \%+$ Fresta F Conc ${ }^{\circledR} 0.02 \%$ ]. Fresta $\mathrm{F}$ Conc ${ }^{\circledR}$ used in experiment included fenugreek (40\%), clove $(12.5 \%)$, cinnamon $(7.5 \%)$ and carrier $(40 \%)$. Experimental diets were fed in three phases (d 0 to 14,14 to 28 and 28 to 49 postweaning). Diets for d 0 to 14 (Table 1 ) were formulated to contain 3,336 kcal/kg of ME, $23.97 \%$ of CP and $1.60 \%$ of lysine and diets for d 14 to 28 (Table 1) were formulated to contain 3,336 kcal/ $/ \mathrm{kg}$ of ME, $21.97 \%$ of CP and $1.40 \%$ of lysine. Also, diets for d 28 to 49 (Table 2) were formulated to contain 3,360 kcal/kg of ME, $20.00 \%$ of CP and $1.30 \%$ of lysine. The diets were formulated to meet or exceed the nutrient requirements recommended by NRC (1998).

Pigs were allowed to consume feed and water ad libitum from self-feeders and nipple waterers. Average daily gain (ADG) and average daily feed intake (ADFI) were measured on d 14, 28 and 49 and gain/feed ratio was also calculated. Chromic oxide $\left(\mathrm{Cr}_{2} \mathrm{O}_{3}\right)$ was added at $0.20 \%$ of diets as a digestible marker on day-10, 24 and 43 and fresh samples were collected. Feed and feces samples were analyzed for DM and N concentrations (AOAC, 1995). Chromium was determined by UV absorption spectrophotometry (Shimadzu, UV-1201, Japan) and apparent digestibilities of DM and $\mathrm{N}$ were calculated using the indirect methods.

Fecal consistency scoring was based on the following index used by Sherman et al. (1983): 0, normal (feces firm and well formed); 1, soft consistency (feces soft and 
Table 2. Diet composition(as-fed basis)

\begin{tabular}{|c|c|c|c|c|}
\hline \multirow{2}{*}{ Ingredient (\%) } & \multicolumn{4}{|c|}{ Phase III } \\
\hline & NC & PC & NCF & PCF \\
\hline Corn & 55.26 & 55.16 & 55.23 & 55.14 \\
\hline Soybean meal (CP 44\%) & 33.43 & 33.43 & 33.43 & 33.43 \\
\hline Animal fat & 5.33 & 5.33 & 5.33 & 5.33 \\
\hline Molasses & 2.50 & 2.50 & 2.50 & 2.50 \\
\hline Dicalcium phosphate & 1.93 & 1.93 & 1.93 & 1.93 \\
\hline Limestone & 0.78 & 0.78 & 0.78 & 0.78 \\
\hline Vitamin premix ${ }^{1}$ & 0.12 & 0.12 & 0.12 & 0.12 \\
\hline Trace mineral premix ${ }^{2}$ & 0.10 & 0.10 & 0.10 & 0.10 \\
\hline Salt & 0.20 & 0.20 & 0.20 & 0.20 \\
\hline L-lysine HCL & 0.17 & 0.17 & 0.17 & 0.17 \\
\hline DL-methionine & 0.03 & 0.03 & 0.03 & 0.03 \\
\hline $\begin{array}{l}\text { Antioxidant } \\
\text { (Ethoxyquin 25\%) }\end{array}$ & 0.05 & 0.05 & 0.05 & 0.05 \\
\hline Essential oils & - & - & 0.03 & 0.02 \\
\hline CSP & - & 0.10 & - & 0.10 \\
\hline \multicolumn{5}{|l|}{ Chemical composition $^{3}$} \\
\hline ME (kcal/kg) & \multicolumn{3}{|c|}{3,360} & \\
\hline Crude protein (\%) & \multicolumn{3}{|c|}{20.00} & \\
\hline Lysine (\%) & \multicolumn{3}{|c|}{1.30} & \\
\hline Methionine (\%) & \multicolumn{3}{|c|}{0.36} & \\
\hline Calcium (\%) & \multicolumn{3}{|c|}{0.90} & \\
\hline Phosphorus (\%) & \multicolumn{3}{|c|}{0.80} & \\
\hline \multicolumn{5}{|c|}{$\begin{array}{l}{ }^{1} \text { Provided per kg diet: } 20,000 \mathrm{IU} \text { of vitamin } \mathrm{A} ; 4,000 \mathrm{IU} \text { of vitamin } \mathrm{D}_{3} ; 80 \\
\mathrm{IU} \text { of vitamin E; } 16 \mathrm{mg} \text { of vitamin } \mathrm{K}_{3} ; 4 \mathrm{mg} \text { of thiamine; } 20 \mathrm{mg} \text { of } \\
\text { riboflavin; } 6 \mathrm{mg} \text { of pyridoxine; } 0.08 \mathrm{mg} \text { of vitamin } \mathrm{B}_{12} ; 120 \mathrm{mg} \text { of } \\
\text { niacin; } 50 \mathrm{mg} \text { of Ca-pantothenate; } 2 \mathrm{mg} \text { of folic acid and } 0.08 \mathrm{mg} \text { of } \\
\text { biotin. } \\
{ }^{2} \text { Provided per kg diet: } 140 \mathrm{mg} \text { of } \mathrm{Cu} ; 179 \mathrm{mg} \text { of } \mathrm{Zn} ; 12.5 \mathrm{mg} \text { of } \mathrm{Mn} ; 0.5 \\
\text { mg of I; } 0.25 \mathrm{mg} \text { of Co and } 0.4 \mathrm{mg} \text { of Se. }\end{array}$} \\
\hline
\end{tabular}

formed); 2, mild diarrhea (fluid feces, usually yellowish); and 3 , severe diarrhea (feces watery and projectile).
The concentrations of red blood cell (RBC), white blood cell (WBC) and lymphocytes in the blood were measured to investigate the effect of essential oils supplementation in weaned pigs. Blood samples were collected via jugular vein into $K_{2}$ vacuum tubes (Becton Dickinson Vacutainer Systems, Franklin Lakes, NJ, USA) from ten pigs in each treatment on the initial and final days of the feeding trial. The concentrations of RBC, WBC and lymphocytes in the blood were measured using the automatic blood analyzer (ADVIA 120, Bayer, USA). The concentrations of total protein, albumin and IgG in the blood serum were measured using the automatic biochemistry analyzer (HITACHI 747, Japan).

Ammonia nitrogen $\left(\mathrm{NH}_{3}-\mathrm{N}\right)$ concentration was determined according to the methods of Chaney and Marbach (1962). Volatile fatty acids (VFA) concentration was analyzed as follows: 2 g fecal samples were obtained and diluted with $8 \mathrm{ml}$ of distilled water. After added 2 drops of concentrated $\mathrm{HCl}$, samples were centrifuged at $17,400 \times \mathrm{g}$ for $10 \mathrm{~min}$. The supernatant was filtered by $0.22-\mu \mathrm{m}$ filter (Millipore Co., Bedford, MA) and analyzed using gas chromatography (Hewlett Packard 6890 Plus, USA). Hydrogen sulfide $\left(\mathrm{H}_{2} \mathrm{~S}\right)$ concentration was analyzed as follows: $300 \mathrm{~g}$ fecal sample were collected, fermented $30 \mathrm{~h}$ in the incubator $\left(35^{\circ} \mathrm{C}\right)$. Samples were measured using the gas search probe (Gastec no. 4, Japan).

\section{Statistical analysis}

The data were analyzed as Latin squares using the ANOVA of SAS (1966). The statistical model included range test (Duncan, 1955) was used to determine significant differences among treatments.

Table 3. Effects of essential oils on growth performance in weaned pigs ${ }^{1}$

\begin{tabular}{|c|c|c|c|c|c|}
\hline Item & $\mathrm{NC}^{2}$ & $\mathrm{PC}^{2}$ & $\mathrm{NCF}^{2}$ & $\mathrm{PCF}^{2}$ & $\mathrm{SE}^{3}$ \\
\hline \multicolumn{6}{|l|}{ 0-14 days } \\
\hline ADG (g) & 189 & 185 & 185 & 212 & 9 \\
\hline ADFI (g) & $251^{\mathrm{c}}$ & $261^{\mathrm{b}}$ & $265^{\mathrm{b}}$ & $287^{\mathrm{a}}$ & 3 \\
\hline Gain/feed & 0.752 & 0.708 & 0.698 & 0.738 & 0.035 \\
\hline \multicolumn{6}{|l|}{ 14-28 days } \\
\hline ADG (g) & $441^{\mathrm{b}}$ & $447^{\mathrm{ab}}$ & $473^{\mathrm{ab}}$ & $477^{\mathrm{a}}$ & 11 \\
\hline ADFI (g) & $446^{\mathrm{c}}$ & $464^{\mathrm{ab}}$ & $466^{\mathrm{ab}}$ & $486^{\mathrm{a}}$ & 5 \\
\hline Gain/feed & 0.988 & 0.963 & 1.015 & 0.981 & 0.029 \\
\hline \multicolumn{6}{|l|}{ 28-49 days } \\
\hline ADG (g) & $593^{\mathrm{b}}$ & $638^{\mathrm{ab}}$ & $643^{\mathrm{ab}}$ & $675^{\mathrm{a}}$ & 16 \\
\hline ADFI (g) & $1,022^{c}$ & $1,049^{\mathrm{bc}}$ & $1,074^{\mathrm{ab}}$ & $1,086^{\mathrm{a}}$ & 11 \\
\hline Gain/feed & 0.580 & 0.608 & 0.598 & 0.621 & 0.017 \\
\hline \multicolumn{6}{|l|}{ Overall } \\
\hline ADG (g) & $434^{c}$ & $450^{\mathrm{bc}}$ & $464^{\mathrm{ab}}$ & $488^{\mathrm{a}}$ & 9 \\
\hline ADFI (g) & $573^{c}$ & $592^{\mathrm{b}}$ & $602^{\mathrm{b}}$ & $620^{\mathrm{a}}$ & 4 \\
\hline Gain/feed & 0.757 & 0.760 & 0.770 & 0.787 & 0.016 \\
\hline
\end{tabular}

${ }^{1}$ Ninety six pigs with average initial body weight of $5.5 \pm 0.11 \mathrm{~kg}$ (SD).

${ }^{2}$ NC: Negative control; PC: Positive control included CSP (CTC+sulfathiazole+penicillin) 0.1\%; NCF: NC diet included FRESTA F Conc 0.03\%; PCF: PC diet included CSP (CTC+sulfathiazole+penicillin) $0.1 \%$ and FRESTA F Conc $0.02 \%$.

${ }^{3}$ Pooled standard error.

${ }^{\mathrm{a}, \mathrm{b}}$ Means in the same row with different superscripts differ $(\mathrm{p}<0.05)$. 
Table 4. Effects of essential oils on nutrient digestibility in weaned pigs ${ }^{1}$

\begin{tabular}{|c|c|c|c|c|c|}
\hline Item (\%) & $\mathrm{NC}^{2}$ & $\mathrm{PC}^{2}$ & $\mathrm{NCF}^{2}$ & $\mathrm{PCF}^{2}$ & $\mathrm{SE}^{3}$ \\
\hline \multicolumn{6}{|l|}{14 days } \\
\hline Dry matter & 67.72 & 66.67 & 68.13 & 68.26 & 0.92 \\
\hline Nitrogen & 71.81 & 72.51 & 74.01 & 72.52 & 0.87 \\
\hline \multicolumn{6}{|l|}{28 days } \\
\hline Dry matter & $86.41^{\mathrm{b}}$ & $87.72^{\mathrm{a}}$ & $88.42^{\mathrm{a}}$ & $87.93^{\mathrm{a}}$ & 0.40 \\
\hline Nitrogen & $87.65^{\mathrm{b}}$ & $87.40^{\mathrm{b}}$ & $88.37^{\mathrm{ab}}$ & $88.85^{\mathrm{a}}$ & 0.34 \\
\hline \multicolumn{6}{|l|}{49 days } \\
\hline Dry matter & 87.74 & 89.08 & 89.63 & 89.40 & 0.73 \\
\hline Nitrogen & $84.45^{\mathrm{b}}$ & $86.00^{\mathrm{ab}}$ & $87.01^{\mathrm{ab}}$ & $88.48^{\mathrm{a}}$ & 0.97 \\
\hline
\end{tabular}

${ }^{1}$ Ninety six pigs with average initial body weight of $5.5 \pm 0.11 \mathrm{~kg}(\mathrm{SD})$.

${ }^{2}$ NC: Negative control; PC: Positive control included CSP (CTC+sulfathiazole+penicillin) $0.1 \%$; NCF: NC diet included FRESTA F Conc 0.03\%; PCF: PC diet included CSP (CTC+sulfathiazole+penicillin) $0.1 \%$ and FRESTA F Conc $0.02 \%$.

${ }^{3}$ Pooled standard error.

${ }^{\mathrm{a}, \mathrm{b}}$ Means in the same row with different superscripts differ $(\mathrm{p}<0.05)$.

Table 5. Effects of essential oils on fecal consistency score in weaned pigs ${ }^{1}$

\begin{tabular}{lcccc}
\hline Item & $\mathrm{NC}^{2}$ & $\mathrm{PC}^{2}$ & $\mathrm{NCF}^{2}$ & $\mathrm{PCF}^{2}$ \\
\hline No. of pigs & 24 & 24 & 24 & 24 \\
2 days & $2(1.0)$ & $2(1.0)$ & $2(1.2)$ & $2(0.9)$ \\
4 days & $2(1.0)$ & $2(0.6)$ & $2(0.6)$ & $2(0.2)$ \\
8 days & $1(0.5)$ & $1(0.6)$ & $1(0.5)$ & $1(0.2)$ \\
14 days & $0(0.5)$ & $0(0.2)$ & $0(0.2)$ & $0(0.2)$ \\
\hline
\end{tabular}

${ }^{1}$ Ninety six pigs with average initial body weight of $5.5 \pm 0.11 \mathrm{~kg}(\mathrm{SD})$.

${ }^{2}$ NC: Negative control; PC: Positive control included CSP (CTC+ sulfathiazole+penicillin) 0.1\%; NCF: NC diet included FRESTA F Conc 0.03\%; PCF: PC diet included CSP (CTC+ sulfathiazole+penicillin) $0.1 \%$ and FRESTA F Conc $0.02 \%$.

\section{RESULTS AND DISCUSSION}

Growth performance of pigs fed experimental diets is presented in Table 3. From d 0 to 14, ADFI was increased in pigs fed PCF diet $(\mathrm{p}<0.05)$. ADG and gain/feed tended to improve in pigs fed PCF diet. However, there were no significant differences among the treatments. From d 14 to 28, pigs fed PCF diet increased ADG and ADFI compared to pigs fed NC diet $(\mathrm{p}<0.05)$. No difference was found among the treatments for gain/feed. From d 28 to 49, ADG and ADFI in pigs fed PCF diet were higher than in pigs fed NC diet $(p<0.05)$. Through the entire experimental period, ADG and ADFI in pigs fed PCF diet were the highest among the treatments $(\mathrm{p}<0.05)$. Our data are in partial agreement with those of Hong et al. (2004), who indicated that the addition of dietary plant extract to weaned pigs affected ADG, ADFI and gain/feed. Also, Holden and McKean (2002) reported that ADG and feed/gain of pigs fed 2 or $3 \%$ botanical were similar to antibiotic treatments and improved over the treatment without antibiotic controls. Kamel (2001) and Silvia (2002) demonstrated that pigs fed complex (essential oil and organic acid) increased ADG and ADFI.

Nutrient digestibility in pigs fed experimental diets is presented in Table 4. On d 14, there were no significant differences in digestibility of $\mathrm{DM}$ and $\mathrm{N}$ among the treatments $(p>0.05)$. On $d 28$, digestibility of dry matter in pigs fed PC, NCF and PCF diets was higher than that of pigs fed NC diet $(p<0.05)$ and treatments with added essential oils were higher than others in digestibility of nitrogen $(\mathrm{p}<0.05)$. Also, on d 49, digestibility of nitrogen in pigs fed PCF diet was the highest among others $(\mathrm{p}<0.05)$. Improvement of digestibility of nitrogen might be due to that blended essential oil (CRINA HC 737) promoted digestion enzymes into the intestine (Köhler, 1997).

Fecal consistency score of pigs fed experimental diets are presented in Table 5. There was no significant difference in fecal consistency score among the treatments $(\mathrm{p}>0.05)$. Fecal consistency score was lowed in all treatments because our nursery room has all-in all-out system to control disease. Hong et al. (2004) reported that fecal consistency score of plant extract (citrus fruit and chestnut tree extract mixture) groups was similar to antibiotic treatment.

Blood profile of pigs fed experimental diets is presented in Table 6. No statistical differences $(\mathrm{p}>0.05)$ were found in RBC counts, WBC counts, lymphocyte counts, total protein and albumin. Serum IgG concentration of PCF treatment were greater than that of others $(p<0.05)$. Essential oils contain eugenol with antibacterial properties (Bauer et al., 2001). Wang et al. (1998) reported that eugenol improved immune ability by increasing synthesis of IgG in body and synthesis of IgA in saliva. Essential oils improved immune response by increasing phagocytosis. However, we can't conclude effects of essential oils about immune response because NCF treatment was similar to NC treatment.

Noxious gas concentration of pigs fed experimental diets is presented in Table 6. On d 14 and 28, no statistical differences ( $p>0.05$ ) were found in VFA, $\mathrm{NH}_{3}-\mathrm{N}$ and $\mathrm{H}_{2} \mathrm{~S}$ concentrations among treatments. On d 49, there was no significant difference in VFA concentration among the treatments ( $p>0.05) . \mathrm{NH}_{3}-\mathrm{N}$ concentration in pigs fed PCF diet was lower than in pigs fed other diets $(p<0.05) . \mathrm{H}_{2} \mathrm{~S}$ concentration in pigs fed diets with added essential oils was lower than in other diets. It is known that ammonia nitrogen and hydrogen sulfide are major sources of environment 
Table 6. Effects of essential oils on blood profile in weaned pigs ${ }^{1}$

\begin{tabular}{|c|c|c|c|c|c|}
\hline Item & $\mathrm{NC}^{2}$ & $\mathrm{PC}^{2}$ & $\mathrm{NCF}^{2}$ & $\mathrm{PCF}^{2}$ & $\mathrm{SE}^{3}$ \\
\hline \multicolumn{6}{|c|}{$\overline{R B C}\left(\times 10^{6} / \mathrm{mm}^{3}\right)$} \\
\hline D 0 & 5.28 & 5.10 & 4.45 & 5.08 & 0.279 \\
\hline D 49 & $5.48^{\mathrm{b}}$ & $6.09^{\mathrm{ab}}$ & $5.83^{\mathrm{ab}}$ & $6.22^{\mathrm{a}}$ & 0.189 \\
\hline Difference & 0.20 & 0.99 & 1.38 & 1.14 & 0.374 \\
\hline \multicolumn{6}{|c|}{ WBC $\left(\times 10^{3} / \mathrm{mm}^{3}\right)$} \\
\hline D 0 & 8.58 & 7.87 & 7.80 & 9.69 & 0.921 \\
\hline D 49 & $9.39^{b}$ & $12.68^{\mathrm{ab}}$ & $12.55^{\mathrm{ab}}$ & $17.15^{\mathrm{a}}$ & 1.529 \\
\hline Difference & 0.81 & 4.81 & 4.75 & 7.46 & 2.3 \\
\hline \multicolumn{6}{|c|}{ Lymphocyte (\%) } \\
\hline D 0 & 32.80 & 38.75 & 47.00 & 41.80 & 5.810 \\
\hline D 49 & 67.20 & 70.60 & 69.40 & 64.80 & 6.342 \\
\hline Difference & 34.40 & 31.85 & 22.40 & 23.00 & 8.110 \\
\hline \multicolumn{6}{|c|}{ Total protein (g/dl) } \\
\hline D 0 & 5.42 & 5.26 & 5.28 & 5.62 & 0.153 \\
\hline D 49 & 5.34 & 5.60 & 5.32 & 5.68 & 0.130 \\
\hline Difference & -0.08 & 0.34 & 0.04 & 0.06 & 0.184 \\
\hline \multicolumn{6}{|l|}{ Albumin (g/dl) } \\
\hline D 0 & 3.68 & 3.70 & 3.56 & 3.70 & 0.122 \\
\hline D 49 & 3.72 & 3.91 & 3.88 & 4.38 & 0.175 \\
\hline Difference & -0.04 & 0.21 & 0.32 & 0.68 & 0.243 \\
\hline \multicolumn{6}{|l|}{ IgG (mg/dl) } \\
\hline D 0 & 268.60 & 249.60 & 256.40 & 270.80 & 7.340 \\
\hline D 49 & $323.60^{\mathrm{b}}$ & $325.40^{\mathrm{b}}$ & $332.40^{\mathrm{b}}$ & $366.20^{\mathrm{a}}$ & 3.008 \\
\hline Difference & $55.00^{\mathrm{c}}$ & $75.80^{\mathrm{b}}$ & $76.00^{\mathrm{b}}$ & $95.40^{\mathrm{a}}$ & 5.931 \\
\hline \multicolumn{6}{|c|}{$\begin{array}{l}{ }^{1} \text { Ninety six pigs with average initial body weight of } 5.5 \pm 0.11 \mathrm{~kg} \text { (SD). } \\
{ }^{2} \text { NC: Negative control; PC: Positive control included CSP (CTC } \\
\text { sulfathiazole+penicillin) 0.1\%; NCF: NC diet included FRESTA F Con }\end{array}$} \\
\hline
\end{tabular}

pollution. Ushid et al. (2002) demonstrated that ammonia concentration in feces was significantly reduced by addition of herb extracts. Sutton et al. (1992) reported that ammonia emission was restrained by $55.5 \%$ in manure by sarsaponin extract. Also, Jeon et al. (1996) found that addition of yucca extract $(0.02 \%)$ decreased ammonia levels in feces. I suggest that addition of essential oils in pigs diets may promote nitrogen digestibility and essential oils have functions that reduce emission of noxious gases.

\section{IMPLICATION}

The public concern about replacement of antibiotic in animal feed industry demands that more effective studies should be observed in the future. From our study, essential oils can be used partly to replace antibiotic in diets for weaned pigs without any effect on growth performance. Also, these seem to have improved nitrogen digestibility and reduction of noxious gas production.

\section{REFERENCES}

AOAC. 1995. Official method of analysis. 16th Edition.
Table 7. Effects of essential oils on noxious gas production in weaned pigs ${ }^{1}$

\begin{tabular}{|c|c|c|c|c|c|}
\hline Item (ppm) & $\mathrm{NC}^{2}$ & $\mathrm{PC}^{2}$ & $\mathrm{NCF}^{2}$ & $\mathrm{PCF}^{2}$ & $\mathrm{SE}^{3}$ \\
\hline \multicolumn{6}{|l|}{14 days } \\
\hline Acetic acid & 1,201 & 1,305 & 1,262 & 1,316 & 134 \\
\hline Propionic acid & 450 & 470 & 407 & 468 & 33 \\
\hline Butyric acid & 540 & 534 & 498 & 516 & 33 \\
\hline $\mathrm{NH}_{3}-\mathrm{N}$ & 812 & 746 & 756 & 788 & 48 \\
\hline $\mathrm{H}_{2} \mathrm{~S}$ & 34.23 & 32.38 & 31.35 & 31.22 & 2.40 \\
\hline \multicolumn{6}{|l|}{28 days } \\
\hline Acetic acid & 1,356 & 1,116 & 1,337 & 1,263 & 77 \\
\hline Propionic acid & 619 & 640 & 570 & 541 & 51 \\
\hline Butyric acid & 522 & 526 & 553 & 648 & 48 \\
\hline $\mathrm{NH}_{3}-\mathrm{N}$ & 790 & 709 & 739 & 692 & 78 \\
\hline $\mathrm{H}_{2} \mathrm{~S}$ & 32.36 & 31.07 & 30.01 & 31.58 & 1.98 \\
\hline \multicolumn{6}{|l|}{49 days } \\
\hline Acetic acid & 1,463 & 1,418 & 1,408 & 1,374 & 102 \\
\hline Propionic acid & 599 & 577 & 505 & 574 & 74 \\
\hline Butyric acid & 540 & 536 & 481 & 507 & 79 \\
\hline $\mathrm{NH}_{3}-\mathrm{N}$ & $871^{\mathrm{a}}$ & $738^{\mathrm{ab}}$ & $652^{\mathrm{ab}}$ & $619^{\mathrm{b}}$ & 70 \\
\hline $\mathrm{H}_{2} \mathrm{~S}$ & $38.11^{\mathrm{a}}$ & $32.15^{\mathrm{ab}}$ & $28.14^{\mathrm{b}}$ & $28.98^{\mathrm{b}}$ & 2.51 \\
\hline \multicolumn{6}{|c|}{$\begin{array}{l}{ }^{1} \text { Ninety six pigs with average initial body weight of } 5.5 \pm 0.11 \mathrm{~kg} \text { (SD). } \\
\text { sC: Negative control; PC: Positive control included CSP (CTC+ } \\
\text { sulfathiazole+penicillin) } 0.1 \% \text {; NCF: NC diet included FRESTA F Conc } \\
0.03 \% \text {; PCF: PC diet included CSP (CTC+sulfathiazole+penicillin) } 0.1 \% \\
\text { and FRESTA F Conc } 0.02 \% \text {. }\end{array}$} \\
\hline
\end{tabular}

Association of Official Analyticla Chemists, Washington, DC. USA.

Bauer, K., D. Garbe and H. Surburg. 2001. Commom Fragrance and Flavor Materials: Preparation, Properties and Uses. Willey-VCH, Weinheim, p. 293.

Chaney, A. L. and E. P. Marbach. 1962. Modified regents for determination of urea and ammonia. Clin. Chem. 8:131.

Duncan, D. B. 1955. Multiple range and multiple $F$ test. Biometrics 11:1.

Guenther, E. 1948. The Essential Oils. D. Van Nostrand, New York. Holden, P. J. and J. D. McKean. 2002. Botanicals for nursery pigs. J. Anim. Sci. 80(Suppl. 1):41(Abstr.).

Hong, J. W., I. H. Kim, O. S. Kwon, B. J. Min, W. B. Lee and K. S. Shon. 2004. Influences of plant extract supplementation on performance and blood characteristics in weaned pigs. AsianAust. J. Anim. Sci. 17(3):374-378.

Jeon, B. S., J. H. Kwang, Y. H. Yoo, J. O. Cha and H. S. Park. 1996. Effects of feeding enzymes, probiotics or yucca powder on pig growth and odor-generating substances in feces. Korean J. Anim. Sci. 38:52-58.

Kamel, C. 2002. Plant extracts in an integrated approach. Feed mix. 6(6):23-25.

Kim, J. W., S. Y. Koh and S. H. Cho. 1994. ELISA for the measurement of IgG concentration in porcine serum. Kor. J. Anim. Sci. 36:453-458.

Köhler, B. 1997. Bericht der mikrobiologischen Untersuchungen bei der Erprobung der Wirsamkeit von CRINA HC 737 im Vergleich zum kon ventionellen Leistungdförderer auf die Mastlestung beim broiler unter Praxisbedingungen. CR cocstract AKZO NOBEL, Staatliches Veterinär-und 
Lebensmitteluntersuchungsamt Potsdam.

NRC. 1998. Nutrient requirement of pigs $\left(10^{\text {th }}\right.$ Ed.) National Research Council, Academy Press. Washington, DC.

SAS. 1996. SAS user guide. Release 6.12 edition, SAS Inst. Inc., Cary, NC, USA.

Sherman, D. M., S. D. Acres, P. L. Sadowski, J. A. Springer, B. Bray, T. J. L. Raybould and C. C. Muscoplat. 1983. Protection of calves against fatal enteric colibacillosis by orally administered Escherichia coli K99-specific monoclonal antibody. Infect. Immun. 42:656-658.

Silvia, P. and J. Asensio. 2002. Additive for performance : Organic acids plus botanicals. Feed in ternational. 3:17-19.
Sutton, A. L., S. R. Goodall, J. A. Patterson, A. G. Mathew, D. T. Kelly and K. A. Meyerholtz. 1992. Effects of odor control compounds on urease activity in swine manure. J. Anim. Sci. 70(Suppl. 1):160(Abstr.).

Ushid, Kazunari, M. Maekawa and T. Arakawa. 2002. Influence of dietary supplemention of herb extracts on volatile sulfur production in pigs large intestine. J. Nurt. Sci. Vitamin. 48:1823.

Wang, R. J., D. F. Li and B. Steve. 1998. Can 2000 years of herb medicine history help us solve problems in the year 2000. In: Biotechnology in the feed industry (Ed. T. P. Lyons and K. A. Jacques). Nottingham University Press. pp. 271-291.

Wenk, C. 2003. Herbs and botanicals as feed additives in monogastric animals. Asian-Aust. J. Anim. Sci. 16(2):282-289. 